\title{
Role of Oral versus Vaginal Misoprostol before Hysteroscopy in Infertile Patients
}

\section{Ahmed Mohamed Abd EL-Wahab AL-Ashkar ${ }^{1 *}$ MSc; Mofeed Fawzy Mohamed ${ }^{1}$ MD; Al-Refaai Abd El-Fattah Marai ${ }^{1}$ MD}

*Corresponding Author:

Ahmed Mohamed Abd EL-Wahab AL-Ashkar droc.ahmed@Gmail.com

Received for publication October 30 , 2020; Accepted November 24, 2020; Published online November 24, 2020.

Copyright 2020 The Authors published by Al-Azhar University, Faculty of Medicine, Cairo, Egypt. All rights reserved. This an openaccess article distributed under the legal terms, where it is permissible to download and share the work provided it is properly cited. The work cannot be changed in anyway or used commercially.

doi: 10.21608/aimj.2020.44403.1329

${ }^{1}$ Obstetrics and Gynecology Department, Faculty of Medicine, Al-Azhar University,Cairo,Egypt.

\begin{abstract}
Background: Hysteroscopy used to detect possible intrauterine causes of infertility. Misoprostol is a prostaglandin El analogue used in cervical ripening before hysteroscopy to soften the cervix and decreases the force required for dilation.

Aim of the work: Comparing the effectiveness of oral versus vaginal misoprostol administered 24 hours before hysteroscopy to facilitate the procedures in infertile patients.

Patients and Methods: Our randomized control prospective study included 120 infertile women requiring hysteroscopy. Divided into three equal groups (Group A) received oral misoprostol with a dosage of 600 $\mu \mathrm{g}$ (200 $\mu \mathrm{g} / \mathrm{g}$ hours), (Group B) received vaginal misoprostol with a dosage of $400 \mu \mathrm{g}(200 \mu \mathrm{g} / 12$ hours) and (group C) control group received oral placebo (one pill of metronidazole / 8 hours). Width of endocervical canal was assessed before the hysteroscope, the ease of entrance and the mean time needed for cervical dilation.

Results: Statistically substantial differences among the oral and vaginal groups $(p<0,009)$ and among the vaginal and control groups and the oral and control groups ( $\mathrm{p}<0,001$ for both). There was a substantial difference in the ease of cervical entry among the vaginal and control groups and the oral and control groups ( $\mathrm{p}<0,001$ for both), but not among the vaginal and oral groups $(\mathrm{p}<0,998)$. The variation in time was not substantial between both the oral and vaginal groups.

Conclusion: Misoprostol is a good cervical ripening agent. The move from the vaginal to the oral path, which more compliance by the patients, could applied without incurring a risk to clinical effectiveness.
\end{abstract}

Keywords: Infertility; hysteroscopy; Misoprostol; cervical ripening.

Disclosure: The authors have no financial interest to declare in relation to the content of this article. The Article Processing Charge was paid for by the authors.

Authorship: All authors have a substantial contribution to the article.

INTRODUCTION

Infertility is either primary or secondary. Primary infertility can be defined as failure within one year of regular unprotected intercourse to achieve a pregnancy. Secondary infertility means failure to conceive after 2 years of continuous marital life without use of contraception after the previous pregnancy ${ }^{16}$. It is generally agreed that a full infertility workup should involve an assessment of the uterine cavity. ${ }^{12}$

The function of hysteroscopy in the infertility investigation is to detect potential intrauterine alterations which might interfere with implantation or development or both concepts ${ }^{6}$, with the advent of miniature hysteroscopy for diagnostic and certain therapeutic interventions, it is possible to conduct hysteroscopy in an office setting (Outpatient hysteroscopy; $\mathrm{OH})$. It is currently recognized as a 'gold standard' examination of intrauterine anomalies. ${ }^{5}$

Detailed inspection of the cervical canal, isthmus and uterine cavity is part of the hysteroscopic examination. The oriented assessment of the uterotubal junction region and the first few millimeters of the tube were attempted with specific regard to the tubal Ostia ${ }^{12}$. Because it allows the endometrium to be directly visualized, hysteroscopy plays an important role in assessing the uterine causes of infertility, since it can identify small lesions that may not be easily detected through other techniques. ${ }^{4}$

Hysteroscopy is correlated with decreased patient discomfort, excellent visualization, and relatively low rates of complications and failure. ${ }^{4}$

Prior to diagnostic hysteroscopy, cervical priming softens the cervix and decreases the force required for dilation ${ }^{2}$, Thus, the risk of procedural complications such as perforation of the uterus, laceration of the cervical, dilation failure and the formation of a false pathway that may happen during cervical entry may be minimized ${ }^{8}$. Cervical ripening is clinically diagnosed by uterine cervix softening, effacement and dilation. ${ }^{15}$

For years, by stimulating collagenolytic activity and proteoglycan synthesis, prostaglandins have been considered important mediators of cervical maturation. ${ }^{14}$ 
Misoprostol is a prostaglandin El analogue, originally accepted by the FDA (Food and Drug Administration). It can be administered either orally or vaginally ${ }^{9}$. It is inexpensive, has short half-life, does not require refrigeration, widely available and being registered in more than 80 countries. $^{3}$

\section{PATIENTS AND METHODS}

This study was done at Al-Hussien Obstetrics \& Gynecology Department during the period from October 1st, 2019 till April 30 ${ }^{\text {st }}, 2020$. Patients were selected from outpatient clinic, and patients admitted in $\mathrm{Al}$ Hussien Obstetrics-Gynecology department. It is a randomized control prospective study. Include 120 infertile women attending to outpatient clinic in reproductive age requiring diagnostic hysteroscopy. Our randomized control prospective study included 120 infertile women requiring hysteroscopy divided into three equal groups (Group A) received oral misoprostol at a $600 \mu \mathrm{g}$ dosage $(200 \mu \mathrm{g} / 8$ hours), (Group B) received vaginal misoprostol with a dosage of $400 \mu \mathrm{g}$ (200 $\mu \mathrm{g} / 12$ hours) and (group C) control group received oral placebo (one pill of metronidazole $500 \mathrm{mg}$ / 8 hours).

The ethics committee approved the study and after proper counseling. All women solicited for enrollment and provided written informed consent.

All patients selected for our study were subjected to the following: Full history taking including age, history of any medical disorders, history of any previous operations and infertility duration. General examination for diseases causing infertility or contraindicate pregnancy. Local examination including inspection of external genetalia, digital palpation, bimanual examination to detect the size of uterus, its position, mobility, any cervical masses, any adnexal masses and Cusco examination. Laboratory investigation including semen analysis of the male. In females including hormonal profile (FSH, LH, PRL, TSH \&Progesterone) and Preoperative investigation (CBC, INR, SGOT, SGPT\&SERUM CREATININE) .Imaging including HSG which was done postmenstrual in absence of infection using Urographine dye and Transvaginal ultrasonography (Two-dimensional ultrasonography of the vagina was conducted on all patients with LOGIC P3 $3.5 \mathrm{MHz}$ probe 2D system at TALAT UNITE El-Hussein university hospital). The hysteroscope used in this study was that of Karl Storz, (Germany 1996). It is a rigid continuous flow panoramic hysteroscopy $25 \mathrm{~cm}$ in length, $4 \mathrm{~mm}$ in diameter with an outer sheath of $5.5 \mathrm{~mm}$ and a 30-degree fibro optic lens. The light source used in this study was a metal halide automatic light source from Circon Acmi G 71A/Germany with 150-watt lamp. A fibro optic cable was connected to the light source and to the hysteroscope. A hysteroscopic camera of Karl Storz Germany, which was fitted to the eyepiece of the optic sheath where it was transmitted to LCD monitor.

After the patient installed in the lithotomy position and after anesthesia, the gynecologist uses sterile gloves and after put together the instruments, checking the flow of the distention medium, the hysteroscope was introduced under direct vision into the cervix. Width of endocervical canal was assessed before the hysteroscope, the ease of entrance and the mean time needed for cervical dilation

The Factors were assessed including: The ease of entrance of the hysteroscope which recorded by the operator as (very difficult, difficult, fair and easy), Post-operative pain, Baseline cervical width of the largest number of Hegar dilators, which could be inserted without resistance into the cervix at the beginning of the procedure, Bleeding during the procedures (no, moderate or severe bleeding). In addition, the period from the introduction of the hysteroscope and the visualization of the uterine cavity in minutes via the external cervical os.

Criteria for inclusion: Female patients aged 20 to 40 years of age, primary or secondary infertility patients and all examination was preformed between the $5^{\text {th }}$ and the $10^{\text {th }}$ days of the cycle.

Criteria for exclusion: Known sensitivity to misoprostol, any systemic disease that contraindicates prostaglandin use (cardiovascular disease, renal failure, hypertension, etc.), Pregnancy, some hysteroscopic contraindication, such as Pelvic inflammatory disease (PID), active cervicitis and excessive uterine bleeding.

Statistical analysis: Statistically the data analyzed using Statistical Package for the Social Sciences (SPSS) version 18.0. The mean \pm standard deviation (SD) was represented as quantitative data. The frequency and percentage were expressed as qualitative data. You can test all possible combinations of groups in exploratory research to determine where the substantial differences are located (typically only if the ' $F$ ' omnibus is significant). We used likert scales to represent ease of cervical dilation observed during hysteroscope into numerical values. The following experiments were carried out: A one-way analysis of variance (ANOVA) when more than two methods were compared. For the comparison of proportions among two qualitative parameters, the Chi-square (X2) significance test was used. Probability (P-value); Pvalue $<0.05$ was deemed to be substantial, $\mathrm{P}$-value $<$ 0.001 was deemed to be extremely substantial. Moreover, the P-vaxlue $>0.05$ was deemed insignificant.

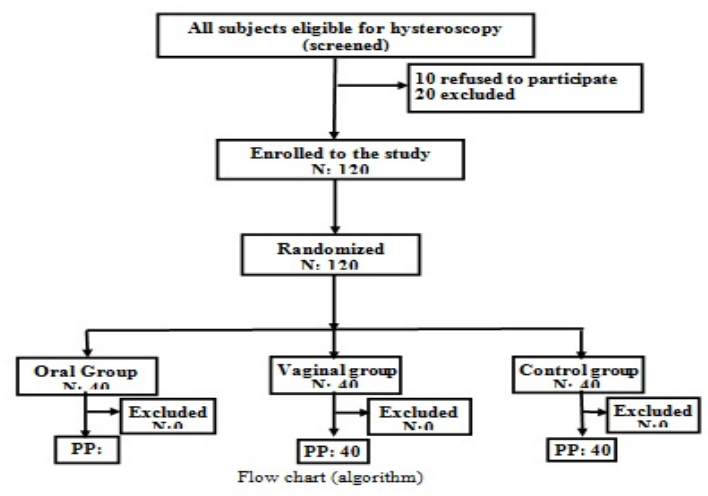

Obstetrics and Gynecology 


\section{RESULTS}

No statistically significant differences $(p>0.05)$ were found between the three age groups. Duration of infertility, parity, history 1ry or 2ry infertility (Table 1).

\begin{tabular}{|c|c|c|c|c|}
\hline Parameters & $\begin{array}{c}\text { Oral } \\
\text { group } \\
\mathbf{N = 4 0}\end{array}$ & $\begin{array}{c}\text { Vaginal } \\
\text { group } \\
\mathbf{N = 4 0}\end{array}$ & $\begin{array}{c}\text { Control } \\
\text { group } \\
\mathbf{N = 4 0}\end{array}$ & $\begin{array}{c}\mathbf{P} \\
\text { value }\end{array}$ \\
\hline $\begin{array}{c}\text { Age , years ,mean } \pm \\
\text { (SD) }\end{array}$ & $\begin{array}{c}33.8 \pm \\
6.80\end{array}$ & $\begin{array}{c}33.2 \pm \\
6.00\end{array}$ & $\begin{array}{c}32.8 \pm \\
5.72\end{array}$ & 0.623 \\
\hline $\begin{array}{c}\text { Duration of infertility } \\
\text { (y) }\end{array}$ & $\begin{array}{c}(1- \\
3) 1.6 \\
\pm 0.8\end{array}$ & $\begin{array}{c}(1-3) 1.5 \\
\pm 0.8\end{array}$ & $\begin{array}{c}(1-3) 1.7 \\
\pm 0.7\end{array}$ & 0.524 \\
\hline Parity ,median , range & $2(0-5)$ & $2(0-5)$ & $2(0-5)$ & 0.756 \\
\hline $\begin{array}{c}\text { History of 1ry } \\
\text { infertility (\%) }\end{array}$ & $27(67)$ & $28(70)$ & $25(65)$ & 0.779 \\
\hline $\begin{array}{c}\text { History of 2ry } \\
\text { infertility (\%) }\end{array}$ & $13(33)$ & $12(30)$ & $15(35)$ & 0.779 \\
\hline
\end{tabular}

Table 1: Characteristics of the groups in the study. In terms of the hysteroscopy indication, three groups have been compared ( $>0.05)$. Endometrial polyps, found in $66 \%$ of cases in the vaginal group, $52 \%$ of cases in the oral group and $50 \%$ of cases in the control group, were the most common indications in the 3 groups. Endometrial hyperplasia, myoma,

\begin{tabular}{|c|c|c|c|c|}
\hline Indication & $\begin{array}{c}\text { Oral } \\
\text { group } \\
\mathbf{n}(\%) \\
\mathbf{N = 4 0}\end{array}$ & $\begin{array}{c}\text { Vaginal } \\
\text { group } \\
\mathbf{n ( \% )} \\
\mathbf{N = 4 0}\end{array}$ & $\begin{array}{c}\text { Control } \\
\text { group } \\
\mathbf{n}(\%) \\
\mathbf{N = 4 0}\end{array}$ & $\begin{array}{c}\mathbf{p} \\
\text { value }\end{array}$ \\
\hline $\begin{array}{c}\text { Endometrial } \\
\text { hyperplasia }\end{array}$ & $3(8)$ & $2(5)$ & $4(10)$ & 0.059 \\
\hline Myoma & $6(15)$ & $5(12)$ & $6(15)$ & 0.152 \\
\hline Polyp & $21(52)$ & $2(66)$ & $20(50)$ & 0.231 \\
\hline Septate uterus & $6(15)$ & $5(12)$ & $8(20)$ & 0.563 \\
\hline $\begin{array}{c}\text { Subseptate } \\
\text { uterus }\end{array}$ & $4(10)$ & $2(5)$ & $2(5)$ & 0.091 \\
\hline
\end{tabular}

Table 2: Indications for hysteroscopy.

The mean width of endocervical canal predilation in the oral group was $4.79 \pm 1.07 \mathrm{~mm}$, in the vaginal group was $4.25 \pm 0.71 \mathrm{~mm}$, and in the control group was $3.92 \pm 0.92 \mathrm{~mm}$. Variations among vaginal and control groups and among oral and control groups in the width of the endocervical canal were statistically significant (p 0.001 for both) and among the oral group and the vaginal one (Table 3 ).

In the oral and vaginal groups, cervical entry was easier than in the control group (mean likert scale, $4.25 \pm 0.64$ vs. $4.22 \pm 0.74$ vs. $2.55 \pm 0.87$ ). There was a substantial difference among the vaginal and control groups and the oral and control groups in the ease of cervical entry (p 0.001 for both), but not among the vaginal and oral groups (p 0.998). (Table 3).

The mean dilation time in the oral group was $48.98 \pm 12.6$ seconds, in the vaginal group, $46.55 \pm 15.32$ seconds, and in the control group, $178.05 \pm 74.18$ seconds (p 0.001). As shown in (Table 3 ), the time difference among both the vaginal and oral groups was not substantial (p 0.987).

\begin{tabular}{|c|c|c|c|c|c|c|}
\hline \multirow[b]{2}{*}{$\begin{array}{l}\text { Groups } \\
\text { Variables }\end{array}$} & \multirow{2}{*}{$\begin{array}{c}\text { Oral } \\
\text { group } \\
\text { Mean } \\
\pm \\
\text { SD }\end{array}$} & \multirow{2}{*}{$\begin{array}{l}\text { Vagin } \\
\text { al } \\
\text { group } \\
\text { Mean } \\
\pm \text { SD }\end{array}$} & \multirow[b]{2}{*}{$\begin{array}{c}\text { Control } \\
\text { group } \\
\text { Mean } \pm \text { SD }\end{array}$} & \multicolumn{3}{|c|}{$P$ values } \\
\hline & & & & $\begin{array}{c}\text { Oral } \\
\text { vs } \\
\text { contr } \\
\text { ol }\end{array}$ & $\begin{array}{c}\text { Vagin } \\
\text { al vs } \\
\text { contr } \\
\text { ol }\end{array}$ & $\begin{array}{c}\text { Oral } \\
\text { vs } \\
\text { vagin } \\
\text { al }\end{array}$ \\
\hline $\begin{array}{c}\text { Endocervi } \\
\text { cal canal } \\
\text { width, } \\
\text { mm }\end{array}$ & $\begin{array}{c}4.79 \\
\pm 1.0 \\
7\end{array}$ & $\begin{array}{c}4.25 \\
\pm \\
0.71\end{array}$ & $3.93 \pm 0.92$ & $\begin{array}{c}0.00 \\
1\end{array}$ & $\begin{array}{c}0.00 \\
1\end{array}$ & $\begin{array}{c}0.00 \\
9\end{array}$ \\
\hline $\begin{array}{l}\text { Ease of } \\
\text { dilation }\end{array}$ & $\begin{array}{c}4.25 \\
\pm \\
0.64\end{array}$ & $\begin{array}{c}4.33 \\
\pm \\
0.74\end{array}$ & $\begin{array}{c}2.55 \pm \\
0.87\end{array}$ & $\begin{array}{c}0.00 \\
1\end{array}$ & $\begin{array}{c}0.00 \\
1\end{array}$ & $\begin{array}{c}0.99 \\
8\end{array}$ \\
\hline $\begin{array}{l}\text { Time } \\
\text { taken to } \\
\text { dilate up } \\
\text { to } 6 \mathrm{~mm} \\
\text { seconds }\end{array}$ & $\begin{array}{c}48.9 \\
8 \\
\pm 12 . \\
6\end{array}$ & $\begin{array}{c}46.55 \\
\pm 15 \\
32\end{array}$ & $\begin{array}{c}178.05 \pm 74 \\
.18\end{array}$ & $\begin{array}{c}0.00 \\
1\end{array}$ & $\begin{array}{c}0.00 \\
1\end{array}$ & $\begin{array}{c}0.98 \\
7\end{array}$ \\
\hline
\end{tabular}

Table 3: Effects on endocervical canal width, ease of dilation and time required for dilation.

In the 3 groups (p 0.05), the negative impacts arising during the research were comparable. Cervical laceration happened in the oral group in 2 cases, the vaginal group in 1 case, and the control group in 4 cases. Postoperative bleeding happened in the oral group in 1 case, the vaginal group in 1 case, and the control group in 3 cases. Post-operative pain happened in the oral group in 3 cases, in the vaginal group in 2 cases, in the control group in 5 cases. Other adverse impacts included cramps, vomiting, nausea, diarrhea, and fever, uterine perforation (false passage) (Table 4).

\begin{tabular}{|c|c|c|c|c|}
\hline Groups & $\begin{array}{c}\text { Oral } \\
\text { group } \\
\text { n (\%) }\end{array}$ & $\begin{array}{c}\text { Vaginal } \\
\text { group n } \\
\text { (\%) }\end{array}$ & $\begin{array}{c}\text { Control } \\
\text { group n } \\
\text { (\%) }\end{array}$ & $\begin{array}{c}\text { P } \\
\text { value }\end{array}$ \\
\hline Cervical lacerations & $2(5)$ & $1(2)$ & $4(10)$ & 0.057 \\
\hline $\begin{array}{c}\text { Postoperative } \\
\text { bleeding }\end{array}$ & $1(3)$ & $1(2)$ & $3(7)$ & 0.051 \\
\hline Preoperative cramps & $2(4)$ & $2(4)$ & $2(4)$ & 1.000 \\
\hline Preoperative diarrhea & $3(5)$ & $0(0)$ & $0(0)$ & 0.194 \\
\hline Preoperative nausea & $3(5)$ & $3(5)$ & $0(0)$ & 0.946 \\
\hline Preoperative vomiting & $3(5)$ & $0(0)$ & $1(2)$ & 0.063 \\
\hline Preoperative fever & $1(3)$ & $1(2)$ & $2(4)$ & 0.773 \\
\hline Postoperative pain & $3(5)$ & $2(4)$ & $5(12)$ & 0.056 \\
\hline $\begin{array}{c}\text { Postoperative uterine } \\
\text { perforation (false } \\
\text { passage) }\end{array}$ & $1(3)$ & $0(0)$ & $2(4)$ & 0.062 \\
\hline
\end{tabular}

Table 4: Adverse events and complications: preoperative and postoperative.

\section{DISCUSSION}

Detailed examination of the cervical canal, isthmus and uterine cavity is included in hysteroscopy. Oriented assessment of the utero-tubal junction region and the first few millimeters of the tube were attempted with specific reference to the Ostia tubal. As it enables the endometrium to be directly visualized, hysteroscopy plays an important role in assessing the uterine causes of infertility, since it can identify small lesions that could not be diagnosed through other approaches. ${ }^{12}$.

The risk of complications may be greatly reduced by using an appropriate approach to promote a smoother, uncomplicated entry during the hysteroscopic procedure. Several cervical ripening modalities have been adopted prior to hysteroscopy. Which supported with Polyzos and Zavos ${ }^{10}$ who 
found that misoprostol seems to promote a hysteroscopy that is smoother and uncomplicated.

By stimulating collagenolytic activity and synthesis of proteoglycans, prostaglandins have been considered the central mediators in cervical ripening, which supported with Sordia-Herna'ndez et al. ${ }^{14}$ who concluded misoprostol is a prostaglandin El analogue like PGE2, Which is capable of promoting an MMP containing leukocyte and monocyte inflow into the cervix.

Our study included 120 women all presented with infertility, 80 patients (66.6\%) presented with primary infertility while 40 patients (33.3\%) presented with secondary infertility. Secondary infertility included patients who had previous living offspring or previous abortions with no living children. The length of infertility varied between 1 and 3 years, and the participants varied from 20 to 40 years of age. Misoprostol was administered at an oral dose of $600 \mu \mathrm{g}$ ( $200 \mu \mathrm{g}$ every 8 hours), 24 hours before the operation, and at a vaginal dose of $400 \mu \mathrm{g}$ (200 $\mu \mathrm{g}$ every 12 hours, 24 hours before the operation).

No statistically significant difference between the most approved (oral) path of misoprostol treatment and the most common path used in our (vaginal) gynecological practice has been shown in our study, 24 hours before hysteroscopy, while others studies showed significant difference. Which supported with: Song et al. $^{13}$ who found that misoprostol administered orally, sublingually and vaginally is equally successful in inducing adequate cervical priming prior to surgical hysteroscopy. Bastu et al. ${ }^{3}$ who found that the use of vaginal misoprostol at doses of $200 \mu \mathrm{g}$ and $400 \mu \mathrm{g}$ greatly facilitated the hysteroscopy procedure compared to the cervical entry controls. The procedural time was shorter, the baseline cervical width was greater and the pain ratings were lower. Increasing the vaginal misoprostol dose from $200 \mu \mathrm{g}$ to $400 \mu \mathrm{g}$, on the other hand, did not increase the impact on cervical dilation. Mulayim et al. $^{9}$ who noticed that prior to hysteroscopy, oral and vaginal routes were successful for cervical priming.

We contrasted the most approved path of administration of misoprostol (oral) with the most popular path used in our gynecologic practice (vaginal) in this randomized controlled study. Our results suggest that before surgical hysteroscopy, both paths are successful and secure for cervical priming. Misoprostol, when administered orally or vaginally, results in an increase in the initial diameter of the endocervical canal and subsequent dilation of the cervix in a substantially shorter time compared to placebo. Oral misoprostol consider the most accepted route, the most common route of drug in take, more compliance, easily administrated by the patient himself and no need for doctors .Vaginal misoprostol associated with less abdominal pain \& cramps, les nausea \& vomiting, fewer diarrheas, less fever less post-operative pain, less incidence of false passage or uterine perforation. Which supported with; SordiaHernandez et al. ${ }^{14}$ who found that vaginal misoprostol at a dosage of $200 \mu \mathrm{g}$ injected 12 hours apart, beginning 24 hours before the office hysteroscope for infertility investigation, decreases pain and time of procedure compared to oral misoprostol and placebo. Also El-Mazny and AbouSalem ${ }^{5}$ they found cervical entry was smoother, the length of the operation was shorter, the acceptability of the patient was higher and the pain rating was lower in the misoprostol group. In addition to Kant and Divyakumar ${ }^{7}$, there was a substantial decrease in cervical resistance and the need for cervical dilation after priming with $400 \mu \mathrm{g}$ of vaginal misoprostol versus placebo $12 \mathrm{~h}$ prior to diagnostic hysteroscopy.

Other studies differ from our study in effectiveness of misoprostol in cervical priming and operative complications and post-operative pain. Such as, AlFozan and Firwana ${ }^{1}$ found the level of evidence that misoprostol promotes preoperative cervical maturation with less complications prior to hysteroscopy is moderate and misoprostol is correlated with major negative impacts, which include preoperative pain and vaginal bleeding. In addition, Singh et al. ${ }^{11}$ found before the diagnosis of hysteroscopy, misoprostol did not make any difference to the easiness of cervical dilation. Although it led a decrease in pain ratings, there was no change in patient satisfaction, analgesia or sedation.

The Lack of consistencies between these different studies due to the initial formulation of misoprostol as an oral agent, extremely variable outcomes have been reported in clinical studies on various routes. It seems logical that in clinical trials of misoprostol, the oral route will be the most appropriate, and actually this is our research. Moreover, in the three groups, complications of the own operation, such as false passage, lacerations of the cervical, perforation of the uterus, and bleeding postoperative, were comparable. In other research, however, misoprostol was proven to positively decrease the occurrence of cervical laceration, control-compared postoperative bleeding, and the strong points of this research comprise the nature of a large sample size as a double blinded, adequately powered trial. In addition, with a variety of metrics calculated as objectively as possible, a head-to-head contrast was presented between routes of administration and sufficient placebo.

This study has limitations with regard to the inability to specify the precise amounts of bleeding deemed significant, variation in the evaluation of ease of dilatation between surgeons, Small sample size of population and Short time of study. Therefore, more prospective studies on large sample within long time should be encouraged.

\section{CONCLUSION}

Misoprostol is a good cervical ripening agent and effective in changing the character of the cervix from harder to be softer. There was no statistically significant differences in the efficacy and safety of cervical priming among oral misoprostol at $600 \mu \mathrm{g}$ ( $200 \mu \mathrm{g}$ every 8 hours), beginning 24 hours before the procedure, and vaginal misoprostol at $400 \mu \mathrm{g}$ (200 $\mu \mathrm{g} 12$ hours apart, beginning 24 hours before the procedure).Therefore, the move from the vaginal
Obstetrics and Gynecology 
path to the oral path, which more compliance by the patients could applied without incurring a risk to clinical effectiveness.

\section{REFERENCES}

1. Al-Fozan H, Firwana B, Al Kadri H, Hassan S and Tulandi T . Preoperative ripening of the cervix before operative hysteroscopy. Cochrane Database Systematic Reviews.2015; CD005998, 10-1002.

2. Bakas P, Hassiakos D and Liapis A. Misoprostol for cervical ripening before diagnostic hysteroscopy in nulliparous women. Int J Gynaecol Obstet. 2012; 116 (3): 263-264.

3. Bastu E, Celik C and Nehir A. Cervical Priming before Diagnostic Operative Hysteroscopy in Infertile Women: A Randomized, Double Blind, Controlled Comparison of 2 Vaginal Misoprostol Doses. Int Surg. 2013; 98: 140-4.

4. El sevier, Dakhny. Accuracy of hysteroscopic endometrial biopsy in diagnosis of adenomyosis, journal of minimally invasive gynecology 2016; 23(3) 364-71.

5. El-Mazny A and Abou-Salem N. A double blind randomized controlled trial of vaginal misoprostol for cervical priming before outpatient hysteroscopy. Fertil Steril. 2011; 96 (4): 962-5.

6. Hassan MM and Gad MTMS. Pregnancy outcome after office micro hysteroscopy in women with unexplained infertility. 2015; 10: 231-5.

7. Kant and Divyakumar. A randomized trial of vaginal misoprostol for cervical priming before hysteroscopy in postmenopausal women . 2011; 91: 141-145.

8. Lee YY, Kim TJ, Kang H, Choi CH, Lee JW and Kim BG. The use of misoprostol before hysteroscopic surgery in non-pregnant premenopausal women: a randomized comparison of sublingual, oral and vaginal administrations. Hum Report. 2010; 25 (8): 1942-8.
9. Mulayim B, Celik NY and Onalan G. Sublingual misoprostol for cervical ripening before diagnostic hysteroscopy in premenopausal women: a randomized, double blind and placebo-controlled trial. Fertil Steril. 2010; 93 (7): 2400-4.

10. Polyzos N.P, Zavos A, Valachis A, Dragamestianos C, Blockeel C, Stoop D, Papanikolaou E.G, Tournaye H, Devroey P and Messinis I.E . Vaginal misoprostol prior to hysteroscopy in premenopausal and postmenopausal women. A systematic review and meta-analysis, Human Reproduction Update .2012; 18(4): 393-404.

11. Singh N and Suneeta Mittal. Vaginal misoprostol for cervical priming prior to diagnostic hysteroscopyefficacy, safety and patient satisfaction: a randomized controlled trial. Arch Gynecol Obstet .2009; 279: 37-40.

12. Siristatidis C, Chrelias C and Salamalekis G. Office hysteroscopy, A current trends and potential applications: a critical review. Arch Gynecol Obstet .2010; 282: 383-8.

13. Song T, Kim MK, Kim ML, Jung YW, Yoon BS and Seong SJ. Effectiveness of different routes of misoprostol administration before operative hysteroscopy: a randomized, controlled trial. Fertil Steril.1014; 102: 519-24.

14. Sordia-Herna'ndez LH, Rosales-Tristan E and Vazquez-Mendez J. Effectiveness of misoprostol for office hysteroscopy without anesthesia in infertile patients. Fertil Steril.2011; 95 (2):759-61.

15. Tanchoco and Aguilar. Randomized controlled study comparing the efficacy of Laminaria versus evening Primrose Oil (EPO) in cervical priming prior to operative hysteroscopy.2017;107: 312-24.

16. Zegers-Hochschild, Adamson GD and Dyer S. the International Glossary on Infertility and Fertility Care. Human Reproduction.2017; 32 (9): 1786-801. 